\title{
International Journal of Social Science and Business: Point Coffee's Digital Communication Strategies Through Post Feeds Instagram @Pointcoffeeid
}

\author{
Mita Sari Kurniawan ${ }^{1 *}$, Rewindinar ${ }^{2}$ \\ 1,2,3 Bunda Mulia University, Jakarta, Indonesia
}

\section{ART I C LE I N F O}

\section{Article history:}

Received July 20, 202

Revised July 23, 2021

Accepted October 21, 2021

Available online November 25, 2021

Keywords:

Media Social, Instagram, Communication Strategy, Point Coffee,Social Strategy

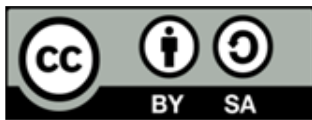

This is an open access article under the CC BY-SA license.

Copyright () 2021 by Author. Published by Universitas Pendidikan Ganesha.

\begin{abstract}
A B S T R A C T
Many new brands are starting to enter the coffee business, one of which is Point Coffee. The emergence of a new coffee shop makes every business person compete to create an attractive brand image and unit to attract consumers' attention. Many coffee choices provide an alternative to buyers in determining purchasing decisions for the products to be used. Marketing is one way to increase product purchases, viz. In marketing, Point Coffee uses Instagram @pointcoffeeid. This article discusses how Point Coffee's digital communication strategy is implemented in @pointcoffeeid's Instagram post feed. This study analyses the Point Coffee digital communication strategy applied to the Instagram @pointcoffeeid Inpost Feed. The research method used is descriptive qualitative using netnographic methods. This analysis was carried out on Instagram content as a data source. The primary data in this study is the post feed content with 155 posts on the @pointcoffeeid Instagram feed. The data analysis technique used is descriptive qualitative and quantitative analysis. The results showed that Point Coffee carried out a digital communication strategy with awareness campaigns, promotions, collaborations, usergenerated content campaigns, and product information. Point Coffee applies a photo posting strategy with a carousel. It is used to collaborate with existing strategies so that Point Coffee ensures product sales so that it can increase awareness and interaction between followers and the @ pointcoffeid account.
\end{abstract}

\section{INTRODUCTION}

The development of culinary business is increasing, especially in the coffee business in Jakarta. Changes in the lifestyle of people who have an interest in meeting with colleagues and enjoying coffee in discussions with partner. Because many new coffee shops have sprung up, therefore every businessman compete in creating attractive brand images and units to attract consumers' attention (H. Han et al., 2018; Rose \& Nofiyanti, 2020). In 2001, Indonesia entered the second wave of the coffee shop industry which was marked by a change in consumer behaviour in drinking coffee, the change from a functional need to an emotional need (Fibriyanti \& Hukama, 2021; Puspa \& Hardiyanti, 2021). Coffee is a type of plantation crop that is cultivated and has economic value, where coffee consumption in the world is recorded at 70 \& Arabica coffee and $26 \%$ for robusta coffee. With the existence of a coffee shop that provides coffee and other beverage products, millennials and young executives choose to enjoy coffee while having a meeting. Contemporary coffee is included in the third generation category of coffee, starting from single origin coffee. Single origin coffee according to regional names such as java coffee, toraja coffee, gayo coffee (Maryani et al., 2020; Rose \& Nofiyanti, 2020).

Based on data from the International Coffee Organization (ICO) has showed that the trend of domestic coffee consumption in Indonesia continues to increase. This can be seen from the graph above, from 2014-2015 there were 4,417 bags. Domestic coffee consumption in Indonesia for the 2015-2016 period reached 4.550 bags. In 2016-2017 reached 4.650 bags. For the 2017-2018 period reached 4.750 bags and continued to increase in 2018-2019, reaching 4,800 bags. That can be concluded that there are more coffee lovers in Indonesia (Rahardjo, 2020; Sihombing et al., 2021). The trend of drinking of contemporary coffee and culture of drink among millennials and young executives has also received attention from business people to compete in making coffee businesses and continue to innovate so that the business 
continues to survive and develop due to intense competition. Look millennial generation's hangout habit, it can be a great opportunity for entrepreneurs and others to do business. The coffee shop is becoming popular gathering place and prestigious among them(Sari, 2020; Widiyanti \& Harti, 2021). The coffee business is also inseparable from technological developments, but is also supported by the ease of obtaining goods (Kurnia \& Afrianto, 2020; Renaldi \& Gunardi, 2021). Because so many options give the alternatives to buyers in determining purchasing decisions for the products to be used (Diansyah \& Nurmalasari, 2017; Prajarini \& Sayogo, 2021). Every company must be able to determine the right strategy so that the business can win the competition and achieved the goals. The company must have to effective marketing strategy to persuade consumer to decide buy the products or services that offered by the company.

With an effective strategy, it can maintain existence and also expand the market. One of important strategies to build a brand in the mind of customers because the brand is an important asset for a company (Marasabessy, 2021; Saputro et al., 2016). Brands are considered as complex symbols that explain attributes, benefits, values, culture and personality for customers (H. Han et al., 2018; Noval et al., 2018). Ability to know a consumer on a brand in different conditions, at the same time can occur with brand recognition and recall go back or memorize on a brand (Kang et al., 2012; Mulyaputri \& Sanaji, 2021). New media are very helpful in today's era with the development of technology to provide efficient communication information through various media that are the morning choices for every user (Sitanggang \& Dharmawan, 2016). During the digitalization period, there was a change in trends from the micro to the macro scale. Currently, social media is used in establishing relationships and disseminating information in promoting an item or service or brand that a company wants to market (Agustinus \& Junaidi, 2020). New media also complements capabilities that do not exist in the mass media and print media (Sitanggang \& Dharmawan, 2016).

As technology develops, Indonesian people, especially Jakarta, always live side by side with technology. Technology is not only used in everyday life. However, it is implemented in several sectors, including the economic sector (Marta \& William, 2016; Yatsenko \& Hritonenko, 2020). The development of information and communication technology makes it easier to carry out promotions and marketing for a company in introducing products to consumers. Beside that, it also make consumers and potential consumers remember and recognize products or services compared to competitors and make consumers to be able to come back to buy and become loyal customers. Technology affects many services in various sectors in line with the industrial revolution 4.0, changes in conventional communication are changing towards digital communication (Sadikin \& Hakim, 2019; Shahroom \& Hussin, 2018). This communication uses digital devices connected to the internet that are not limited by space and time. The existence of this advantage can transfer information that has been prepared, processed, and disseminated by many business people (MacLachlan et al., 2018; Paramita \& Irena, 2020). With the advancement of technology which is growing nowadays make it easier for entrepreneurs in promoting by social media Instagram (Paramita \& Irena, 2020).

Social media is used as a means of communication and establishing relationships with their audience, and each individual uses social media to interact and share information so that company or organization can produce a message in accordance with the goals of the company (Reilly \& Hynan, 2014; Zheng et al., 2018). The development of communication and information techno vcbflogy encourages an institution or company to use social media such as Twitter, Facebook, Instagram as a place to provide information to the public (Birim, 2016; Marta et al., 2019). Businessman must have an awareness that packaging or identity/branding through social media that is created and used must be able to be uniquely involved and attractive (Ardhanariswari et al., 2020). Instagram is used as a promotional medium where Instagram as a popular social networking site in publishing photos or videos with more than 200 million users (Ievansyah \& Sadono, 2018; Perea et al., 2021). Promotion as an activity contained in marketing in introducing a product, every company utilizes technology, namely the use of social media or what is known as social media marketing. In increasing awareness, the image of a company and also increasing sales, companies use online social media as a means of activity to attract consumers from various forms provided such as writing, images, and others (Rachman, 2019). A study conducted by Simply Measured revealed that as many as 54 percent of well known companies using Instagram as medium promotion (Kurnianto et al., 2020).

As is social strategy social media promotion as a form of marketing communication with users or consumers and from consumers can provide a reciprocal relationship that can be used as an input and evaluation for the company (Chu et al., 2020; Rachman, 2019). The theory used in this research is the online media theory by Pierre Levy which discusses the development of media, this theory is the digitization of an understanding concept of the times regarding technology and science from everything that is manual to automatic and from complicated to shortly (Ilhami et al., 2014). This theory is closely related to the to the development of communication technology, with the existence of social media as a new media, the 
researchers consider this theory relevant to existence of social media (Naingolan, Yunita, 2018). PT Indomarco Primatama in collaboration with PT Inti Idola Anugerah opened a coffee shop in Indomaret with brand point coffee in 2016 which are located in strategic locations such as campuses, apartments, rest areas, MRT and others. This is a challenge for Point Coffee in communicating to the public as its target market that Point Coffee those in Indomaret sell coffee products. Indomaret is already known and attached to the community that Indomaret is engaged in the line of business convenience store. The formulation of the problem in this research is how Point Coffee's digital communication strategy is implemented in post feeds Instagram @ @ointcoffeeid. So this study aims to analyze Point Coffee's digital communication strategy which is applied to the @ pointcoffeeid Instagram Feed Inpost.

\section{METHODS}

The approach used in this study is a descriptive qualitative approach in providing a clear picture of the situation (Isa Mulyadi \& Zuhri, 2020). This study uses a netnographic method, with an approach that looks at online interactions. This study uses content analysis (Surijah et al., 2017). This analysis is done on the Instagram's content as a data source. This research is to find out how the Instagram Point Coffee manage their digital communication strategies. The primary data in this study are content post feeds from November 2020-April 2021 with 155 posts on the @pointcoffeeid Instagram feed. In this article, the writer will analyze how Point Coffee's digital communication strategy is implemented in post feeds Instagram $@$ pointcoffeeid. The technique used to analyze the data is descriptive qualitative and quantitative analysis.

\section{RESULTS AND DISCUSSIONS}

\section{Results}

The discussion in this tudy is to analyze the content on the Instagram @pointcoffeeid post feed as a form of digital communication strategy used to build brand awareness for the audience. This analysis is taken from the duration of November 2020 to April 2021 on the Point Coffee Instagram feed. During the 6 month period there were 155 photo post uploaded in the form single photos or carousels which are described in the following Table 1.

Table 1. The Strategy Used by Instagram Point Coffee

\begin{tabular}{|c|c|c|c|c|c|c|}
\hline Strategy & $\begin{array}{c}\text { November } \\
2020\end{array}$ & $\begin{array}{c}\text { December } \\
2020\end{array}$ & $\begin{array}{c}\text { January } \\
2021\end{array}$ & $\begin{array}{c}\text { February } \\
2021\end{array}$ & $\begin{array}{r}\text { March } \\
2021\end{array}$ & $\begin{array}{l}\text { April } \\
2021\end{array}$ \\
\hline Promotion & $36.5 \%$ & $41.2 \%$ & $40 \%$ & $33.3 \%$ & $24.5 \%$ & $38 \%$ \\
\hline Collaboration & $7.7 \%$ & $6 \%$ & $12.8 \%$ & $20 \%$ & $22.6 \%$ & $17.5 \%$ \\
\hline Awareness & $9.7 \%$ & $5.8 \%$ & $3.6 \%$ & $1.7 \%$ & $3.8 \%$ & $3.2 \%$ \\
\hline \multicolumn{7}{|l|}{ User Generated } \\
\hline Content & $3.8 \%$ & $3.9 \%$ & $3.6 \%$ & $6.6 \%$ & $1.9 \%$ & $3.2 \%$ \\
\hline Product Information & $42.3 \%$ & $43.1 \%$ & $40 \%$ & $38.4 \%$ & $47.2 \%$ & $38.1 \%$ \\
\hline
\end{tabular}

A campaign as a form of persuasion activities used by companies by achieve goals. Through Instagram, Point coffee can be seen several digital communication strategies that have been carried out. Instagram Point Coffee carry out several strategies, namely campaigns awareness, promotion, collaboration, campaign User Generated Content, product information. Point Coffee uses a communication pattern with a simple and informative communication approach. Point Coffee organizes feeds and combines the types of strategies that have been used. On campaign strategy awareness Point Coffee applies on National Holidays or certain events that are celebrated by the people of Indonesia. From the picture above is one example that Point Coffee uses in increasing the visibility of companies and products. To reach a new audience, Point Coffee features design something different and interesting in congratulating Good Friday, Christmas, New Year, Valentine's Day etc. The sales with special promotions are used Point Coffee in giving appreciation to customers and followers by giving free upgrade, discount (discounted price), purchase buy 2 get 1 free. This strategy received an overwhelming response from follower, it can be seen from the interactive between followers and admin @pointcoffeedid who answers every comment which exists. Point Coffee also uses Instagram as a two-way communication so that it provides good service for input, appreciation expressed by customers through the comment column feature. 
Other digital communication strategies used are collaboration with products sold at Indomaret, collaboration with the use of BRI cards, and also collaboration with artists or celeb endorsers. Collaboration with Indomaret products, namely light snacks that are indeed in accordance with the culture of young Indonesians with snacks that are very suitable for coffee drinks and other fresh drinks. Collaboration with i-Saku app to get merchandise limited edition of current films tred, the above example is the product of the film Justice League. The communication that I want to build is about people who don't want to try the products from Point Coffee to be interested in buying because of their existence merchandise Preferred. Endorser collaborations collaborate with young artists due to the target market Point Coffee are millennials. This is offset by followers every endorser invited to cooperate who is a millennial child is in accordance with the company's target. By purchasing products from point Coffee, launching new products and providing excellence and quality. Point Coffee also cooperates with celebrity or celebgram in building crowd in building the image of Point Coffee.

Point Coffee chooses endorsers by looking at the credibility of a good source and matches the target market. By choosing the right endorser like the example of Natasha Wilona. She can improve the quality of messages conveyed about brand and product Point Coffee. Natasha Wilona is an actress with 33.8 million followers who will attract the attention of her followers because Natasha has beautiful face and also very talented. So that it becomes a special attraction (charisma). Natasha has worked since 2008 as an model and become an actress, so people can trust her because of Natasha's experinces. The target market of Point Coffee is young people who have similarities with Natasha who is still 22 years old according to and the same as the target of Point Coffee. One of the digital communications used is the campaign User Generated Content (UGC). The UGC campaign is divided into 2 categories, namely challenges / give away and interactive quiz. One of the campaigns carried out by Point Coffee is share your best photo to win free and exclusive drinks merchandisers. On the photo that posted informed about the terms and conditions that must be complied with in order to win giveaway this. Challenge This makes Instagram account users who have not followed the @pointcoffeeid account to take action to follow and upload photos introducing the product. In addition, after doing this, followers will also interact in the comments column and report that they have completed challenge that. There are giveaway and interactive quizzes with mention or tag a friend, that's the way to reach followers new and can find out what flavors are preferred by Point Coffee connoisseurs.

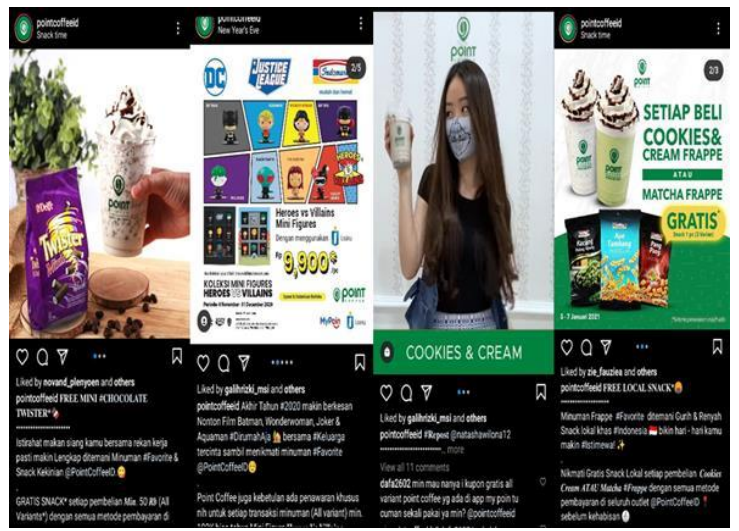

Picture 1. Post Feed Instagram@pointcoffeid for Promotion Strategy

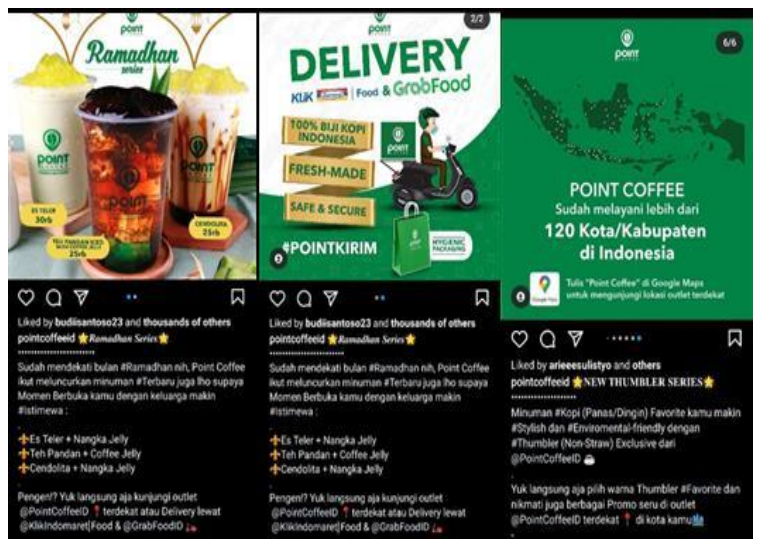

Picture 2. Post Feed Instagram@pointcoffeid for Information Product

In its feeds, Point Coffee's Instagram consistently informs Point Coffee products with a minimum of 22 to 27 post feeds each month, what payment features are available at Point Coffee. Point Coffee does a consistent pattern to inform Point Coffee products/product features so that it indirectly increases the popularity, awareness and memory of Point Coffee.

Table 1. Types of Uploaded Content Instagram@pointcoffeeid

\begin{tabular}{lcccccc}
\hline $\begin{array}{l}\text { Type of } \\
\text { Contents }\end{array}$ & November & December & January & February & March & April \\
& $\mathbf{2 0 2 0}$ & $\mathbf{2 0 2 0}$ & $\mathbf{2 0 2 1}$ & $\mathbf{2 0 2 1}$ & $\mathbf{2 0 2 1}$ & $\mathbf{2 0 2 1}$ \\
\hline Single & $8 \%$ & $7.5 \%$ & $0 \%$ & $4 \%$ & $4 \%$ & $4 \%$ \\
Carousel & $92 \%$ & $92.5 \%$ & $100 \%$ & $96 \%$ & $96 \%$ & $96 \%$ \\
\hline Total & $\mathbf{1 0 0 \%}$ & $\mathbf{1 0 0 \%}$ & $\mathbf{1 0 0} \%$ & $\mathbf{1 0 0 \%}$ & $\mathbf{1 0 0 \%}$ & $\mathbf{1 0 0} \%$ \\
\hline
\end{tabular}


Point Coffee chose to upload more photos than videos and chose photos that uploaded more carousels than single photo. Features carousel is a photo or video sharing feature in one upload. In features carousel, there is a photo slide so that Instagram account users can slide photos left and right for the next photo to be uploaded to be viewed. If seen from post feed @pointcoffeeid, carousel photo interaction is higher than other content and can be seen from the number of photos like and comments. Point Coffee chose a colour design according to the dominant colour of green and combined with white, in accordance with the logo of Point Coffee.

\section{Discussion}

Point Coffee pays attention to make attraction caption and customized campaign taglines. Point Coffee use persuasive promotional language for writing captions. The communication process with the post schedule that has been arranged and has different characteristics will provoke emotionally for followers by looking at the visualization of the combination of photos and graphics used, colour combinations and the uploading tagline (Juwita, 2017; Pertiwi \& Irwansyah, 2020; Priadana \& Murdiyanto, 2020). Point Coffee provides information such as product information, launch new products, and caption what attracts Instagram users can take an action. Captions in the form of questions are considered effective in creating interaction with followers and the comment column will be crowded with follower's responses. If the admin gives questions of facts or challenges, in the comments sections also mentions each other usernames and fellow followers also interact with each other.

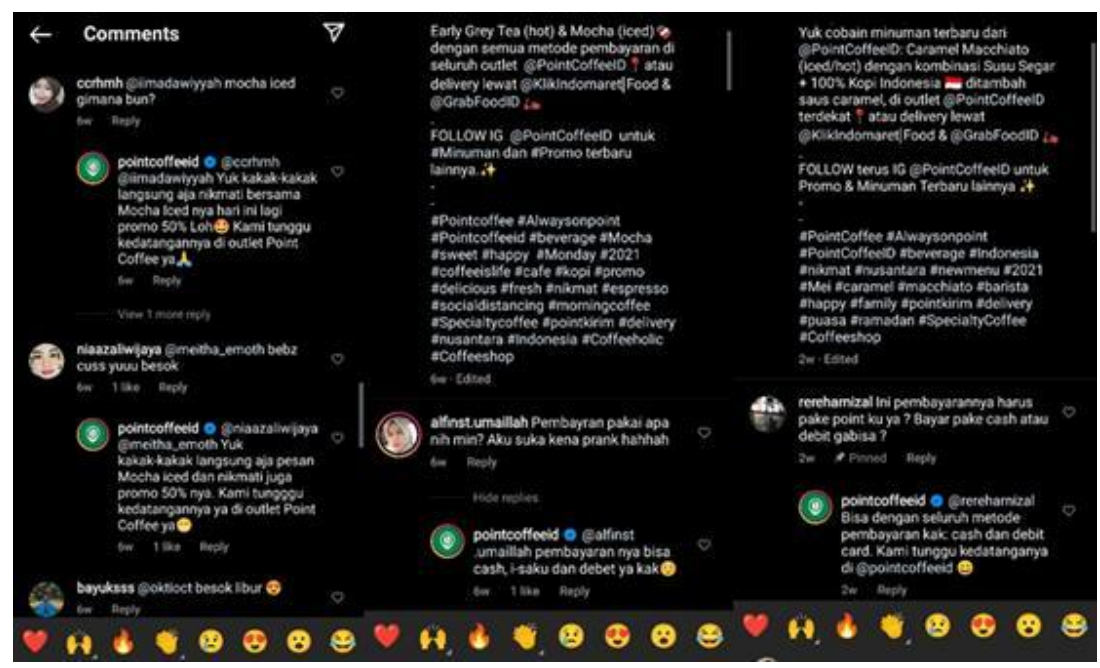

Picture 3. Interactions on @pointcoffeid

Through the comments feature, Instagram users can provide feedback or related questions post from @pointcoffee.id, @pointcoffee.id responded well and interactively to each comment (Aripradono, 2020; Fithriya, 2020). Every question is answered in a friendly manner even with emotions conveyed through emoticons. It can be seen that @pointcoffee builds a social strategy through Instagram media in building awareness to finally make a purchase decision. In addition, Point Coffee utilizes the hashtag feature (\#) which is the mainstay of every Point Coffee post, namely \#PointCoffee \#Alwaysonpoint \#PointCoffeeID, additional hashtag features are adjusted to each post so that it raises the ability of consumer users including followers @pointcoffeeid in recognizing and recognizing a brand, name, logo, and slogan used by Point Coffee, namely Always on point in promoting products.

Technology namely through social media can bring company to unpredictable situasions but with social media can at the same time be an effective tool in overcoming crises. Social media is a new media as a space that allow extraordinary interaction from users (B. Han \& Han, 2016; Lai \& Tai, 2021; Rewindinar et al., 2020). The communication process built by Point Coffee through a digital strategy aims to influence the audience so that they are persuaded and do something that is being campaigned for. That explain that persuasion is inherent in campaigning, every strategies that used by Point Coffee in principle an an act of persuasion use media digital Instagram (Gon, 2021; Johnson et al., 2021; Vendemia et al., 2021). In this research, there are seceral stages that must be carried out as a digital communication strategy through social media, including monitoring social media so as to ensure there are no mistakes in uploading, the speed of responding to questions or comments that appear in accordance with new media theory(Atiko et al., 2016; Longobardi et al., 2020). Beside that, from existing comment Point Coffee should know what target 
market wants with to do research. This is supported by content and captions by asking what kind of favorite product from Point Coffee.

Point Coffee makes on going campaigns such as upload contect as a form of product information, Coffee makes on going campaigns such as upload contect as a form of product information, promotions and also do on going strategy in building brand awareness. This is done by user generated content, awareness, launching new product, so that can bring followers on Instagram @pointcoffeeid. This adjusted to a cleas schedule and goals of this company (Prajarini \& Sayogo, 2021). This is also in line with research that the is an influence post design on purchase intention coffee products in Sleman. For make a content post Instagram needs to pay attention to images, colors, copy writing, and call to action. This support the theory of new media which allows people to develop knowledge and engage more interactively in more flexible media environment. In another research showed that marketing media is more effective and efficient to reach market (Teguh \& Ciawati, 2020). An effective management strategy can be applied in various ways, optimizing Instagram with upload contents which is evoke the emotions. Beside that, use hastags or post interactive content. Following ongoing trends and also have a plan within the specified period in the management of digital marketing communication.

\section{CONCLUSION}

Based on the research, it can be concluded that Point Coffee carries out a digital communication strategy through Instagram @pointcoffeeid social media, namely the campaign awareness, promotion, collaboratiom, campaign User Generated Content, and product information. The strategy most often by Point Coffee from November 2020-April 2021 are the combination of product information and promotions. The strategy also gets feedback the largest seen from the number likes and comments. Point Coffee had implements strategy post photo with the carousel. The research can be concluded that admin @ pointcoffeeid building emotional bonds with the customers. This was done by interaction with the followers which is answer every single comment in the comments sections and give the emoticon that give more attention to the followers. Customers will be interested and buy Point Coffee, and good service will make repeact purchase decisions.

\section{REFERENCES}

Agustinus, A., \& Junaidi, A. (2020). Pengaruh Sosial Media (Instagram) dalam Meningkatkan Brand Awareness Kopi Kenangan. Prologia, 4(2), 339. https://doi.org/10.24912/pr.v4i2.6605.

Ardhanariswari, K. A., Wijayani, A., Probosari, N., Pertanian, F., Dagang, M., Intelektual, K., \& Situasi, A. (2020). Strategi Branding Melalui Sosial Media Dan Perlindungan HKI pada UMKM Kopi Wonogiri. Prosiding Seminar Nasional Ke 6 LPPM UPN “Veteran" Yogyakarta, 57-66.

Aripradono, H. W. (2020). Penerapan Komunikasi Digital Storytelling Pada Media Sosial Instagram. Teknika, 9(2). https://doi.org/10.34148/teknika.v9i2.298.

Atiko, G., Sudrajat, R. H., \& Nasionalita, K. (2016). Analisis Strategi Promosi Pariwisata Melalui Media Sosial Oleh Kementerian Pariwisata RI (Studi Deskriptif Pada Akun Instagram @Indtravel). Jurnal Sosioteknologi, 15(3), 378-389. https://doi.org/10.5614/sostek.2016.15.3.6.

Birim, B. (2016). Evaluation of Corporate Social Responsibility and Social Media as Key Source of Strategic Communication. Procedia - Social and Behavioral Sciences, 235. https://doi.org/10.1016/j.sbspro.2016.11.026.

Chu, S.-C., Chen, H.-T., \& Gan, C. (2020). Consumers' engagement with corporate social responsibility (CSR) communication in social media: Evidence from China and the United States. Journal of Business Research, 110. https://doi.org/10.1016/j.jbusres.2020.01.036.

Diansyah, \& Nurmalasari, A. I. (2017). Pengaruh Pemasaran Internet Dan Electronic Word Of Mouth Terhadap Keputusan Pembelian Dengan Kesadaran Merek Sebagai Variabel Intervening Pada Mahasiswa Universitas 17 Agustus 1945 Jakarta. Journal of Business Studies, 2(1), 84-98.

Fibriyanti, N. A., \& Hukama, L. D. (2021). Niat beli ulang mahasiswa terhadap kopi berkonsep coffee-to-go shop. Jurnal Manajemen Maranatha, 20(2), 185-196. https://doi.org/10.28932/jmm.v20i2.3574.

Fithriya, D. N. L. (2020). Capaian Unggahan Konten Akun Instagram Gembira Loka Zoo (Glzoo) Yogyakarta Terhadap Online Engagement Pada Masa Pandemi Covid-19. Jurnal Sosiologi Reflektif, 15(1). https://doi.org/10.14421/jsr.v15i1.1980.

Gon, M. (2021). Local experiences on Instagram: Social media data as source of evidence for experience $\begin{array}{lllll}\text { design. Journal of Destination Marketing \& Management, } 19 . & \end{array}$ https://doi.org/10.1016/j.jdmm.2020.100435. 
Han, B., \& Han, B. (2016). Social Media Burnout : Definition , Measurement Instrument , and Why We Care Social Media Burnout: Definition, Measurement Instrument, and Why We Care. Journal of Computer Information Systems, 00(00), 1-9. https://doi.org/10.1080/08874417.2016.1208064.

Han, H., Nguyen, H. N., Song, H., Chua, B.-L., Lee, S., \& Kim, W. (2018). Drivers of brand loyalty in the chain coffee shop industry. International Journal of Hospitality Management, 72. https://doi.org/10.1016/j.ijhm.2017.12.011.

Ievansyah, I., \& Sadono, T. P. (2018). Personal Branding Dalam Komunikasi Selebritis (Studi Kasus Personal Branding Alumni Abang None Jakarta Di Media Sosial “Instagram”). Bricolage : Jurnal Magister Ilmu Komunikasi, 4(02), 149. https://doi.org/10.30813/bricolage.v4i02.1658.

Ilhami, F., Santoso, H., \& Setyabudi, D. (2014). Pengaruh Terpaan Pemberitaan Politik di Media Online dan Terpaan Pesan Iklan Kampanye Politik di Media Televisi Terhadap Elektabilitas Partai Hanura. Jurnal ILMU KOMUNIKASI, 2(2), 1-94.

Isa Mulyadi, A., \& Zuhri, S. (2020). Analisis Strategi Brand Image Kedai Kopi “MOENG KOPI” Melalui Media Sosial Instagram. Jurnal Ilmu Komunikasi, 10(2), 109-124. https://doi.org/10.15642/jik.2020.10.2.109-124.

Johnson, A., Khan, S., \& Koo, E. B. (2021). Social media and vision therapy: Perspectives of providers and patients on Instagram. Journal of American Association for Pediatric Ophthalmology and Strabismus, 25(3). https://doi.org/10.1016/j.jaapos.2020.11.023.

Juwita, R. (2017). Media Sosial dan Perkembangan Komunikasi Korporat. Jurnal Penelitian Komunikasi, 20(1). https: //doi.org/10.20422/jpk.v20i1.136.

Kang, J., Tang, L., Lee, J. Y., \& Bosselman, R. H. (2012). Understanding customer behavior in name-brand Korean coffee shops: The role of self-congruity and functional congruity. International Journal of Hospitality Management, 31(3). https://doi.org/10.1016/j.ijhm.2011.09.017.

Kurnia, F. M., \& Afrianto, I. (2020). Pembangunan Aplikasi Transaksi Menu Di Kedai XYZ Kopi Menggunakan QR-Code Dan One Time Password Berbasis E-Wallet. Matrix: Jurnal Manajemen Teknologi Dan Informatika, 10(3). https://doi.org/10.31940/matrix.v10i3.1919.

Kurnianto, Y. T. R. I., Kurnianto, Y. T. R. I., Sebagai, I., Promosi, M., \& Minuman, P. (2020). Pemanfaatan Media Sosial Instagram Sebagai Media Promosi Pemasaran Minuman Di Banjarbaru ( Studi Pada Akun Instagram @ tempatbiasa.kopi).

Lai, C., \& Tai, C.-P. (2021). Types of social media activities and Hong Kong South and Southeast Asians Youth's Chinese language learning motivation. 97. https://doi.org/10.1016/j.system.2020.102432.

Longobardi, C., Settanni, M., Fabris, M. A., \& Marengo, D. (2020). Follow or be followed: Exploring the links between Instagram popularity, social media addiction, cyber victimization, and subjective happiness in Italian adolescents. Children and Youth Services, 113. https: //doi.org/10.1016/j.childyouth.2020.104955.

MacLachlan, M., Banes, D., Bell, D., Borg, J., Donnelly, B., Fembek, M., Ghosh, R., Gowran, R. J., Hannay, E., Hiscock, D., Hoogerwerf, E. J., Howe, T., Kohler, F., Layton, N., Long, S., Mannan, H., Mji, G., Odera Ongolo, T., Perry, K., ... Hooks, H. (2018). Assistive technology policy: a position paper from the first global research, innovation, and education on assistive technology (GREAT) summit. Disability and Rehabilitation: Assistive Technology, 454-466. https: //doi.org/10.1080/17483107.2018.1468496.

Marasabessy, A. I. (2021). Membangun Bisnis Di Masa Pandemi Covid-19 (Studi Kasus Pada Kedai Kopi "MM" Di Kota Ambon). Jurnal Bisnis Dan Kewirausahaan, 17(2). https: //doi.org/10.31940/jbk.v17i2.2338.

Marta, R. F., Fernando, J., \& Simanjuntak, R. F. (2019). Eksplikasi Kualitas Konten Peran Keluarga Pada Instagram @Kemenppa. ETTISAL: Journal of Communication. https://doi.org/10.21111/ejoc.v4i2.3702.

Marta, R. F., \& William, D. M. (2016). Studi Terpaan Media Pemasaran Melalui Posting Instagram Terhadap Ekuitas Merek Pelanggan Sumoboo! (Analisis Eksplanatif pada Komunitas Food Blogger \#WTFoodies). Jurnal Komunikasi, 8(1). https://doi.org/10.24912/jk.v8i1.50.

Maryani, D. Y., Rochdiani, D., \& Setia, B. (2020). Strategi Pengembagan Bisnis Kedai Kopi“Ai Coffee” Di Desa Pakemitan Kecamatan Ciawi Kabupaten Tasikmalaya. Jurnal Ilmiah Mahasiswa, 7(3). https://doi.org/10.25157/jimag.v7i3.4007.

Mulyaputri, V. M., \& Sanaji, S. (2021). Pengaruh Viral Marketing dan Brand Awareness terhadap Niat Beli Merek Kopi Kenangan di Kota Surabaya. Jurnal Ilmu Manajemen, 9(1), 91. https: //doi.org/10.26740/jim.v9n1.p91-101. 
Naingolan, Yunita, M. Z. dan F. A. (2018). Penggunaan Media Sosia Instagram Untuk Menunjang Peran Duta Wisata 2016-2017 Dalam Mempromosikan Pariwisata Kalimantan Timur. E-Journal Ilmu Komunikasi, Volume 6(No 3), 136-148.

Noval, T. M., Soegoto, A. S., \& Ogi, I. W. J. (2018). Pengaruh Ekuitas Merek Dan Strategi Penetapan Harga Terhadap Nilai Pelanggan Boulevard D'Coffee Aceh. Jurnal EMBA, 6(4), 2958-2967. https: //doi.org/10.35794/emba.v6i4.21204.

Paramita, S., \& Irena, L. (2020). Retorika Digital dan Social Network Analysis Generasi Milenial Tionghoa melalui Youtube. Jurnal Komunikasi, 12(1), 137. https://doi.org/10.24912/jk.v12i1.7558.

Perea, D., Bonsón, E., \& Bednárová, M. (2021). Citizen reactions to municipalities' Instagram communication. Government Information Quarterly, 38(3). https://doi.org/10.1016/j.giq.2021.101579.

Pertiwi, F., \& Irwansyah, I. (2020). Personal Branding Ria Ricis pada Media Sosial Instagram. Jurnal Penelitian Komunikasi, 23(1). https: //doi.org/10.20422/jpk.v23i1.631.

Prajarini, D., \& Sayogo, D. (2021). Pengaruh Desain Post Instagram Terhadap Minat Pembelian Produk Umkm Kedai Kopi Di Kabupaten Sleman. Andharupa: Jurnal Desain Komunikasi Visual \& Multimedia, 7(1). https://doi.org/10.33633/andharupa.v7i01.4139.

Priadana, A., \& Murdiyanto, A. W. (2020). Analisis Waktu Terbaik untuk Menerbitkan Konten di Instagram untuk Menjangkau Audiens. Jurnal Penelitian Pers Dan Komunikasi Pembangunan, 24(1). https: //doi.org/10.46426/jp2kp.v24i1.118.

Puspa, R., \& Hardiyanti, N. Y. (2021). Coffee Culture Di Indonesia: Pola Konsumsi Konsumen Pengunjung Kafe, Kedai Kopi Dan Warung Kopi Di Gresik. Jurnal Media Dan Komunikasi, 2(1). https://doi.org/10.20473/medkom.v1i2.26380.

Rachman, R. A. (2019). Analisis Social Strategy Akun iPusnas Pada Media Sosial Instagram Sebagai Media Promosi Bagi Generasi Milenial. February, 736-746.

Rahardjo, B. (2020). Analysis and strategy for improving Indonesian coffee competitiveness in the international market. Bisnis Dan Management, 12(2). https://doi.org/110.26740/bisma.v12n2.p154-167.

Reilly, A. H., \& Hynan, K. A. (2014). Corporate communication, sustainability, and social media: It's not easy (really) being green. Business Horizons, 57(6). https://doi.org/10.1016/j.bushor.2014.07.008.

Renaldi, D., \& Gunardi. (2021). Pengaruh Layanan Go Food dan Penetapan Harga Terhadap Volume Penjualan di PT Evismandalia Anugrah (Kopi Kohi). Jurnal Fair Value, 4(1), 194-203. https://doi.org/10.32670/fairvalue.v4i1.503.

Rewindinar, Triputra, P., \& Napitupulu, F. (2020). Hashtag Construction as Product of Symbolic Convergence: Berger and Luckmann's Approach. Journal of Education, Society and Behavioural Science, 33(11), 1-14. https: //doi.org/10.9734/jesbs/2020/v33i1130267.

Rose, T., \& Nofiyanti, F. (2020). Citra Merek Terhadap Minat Beli Konsumen Kopi Kekinian di Jakarta. LITERATUS. https://doi.org/10.37010/lit.v2i1.33.

Sadikin, A., \& Hakim, N. (2019). Pengembangan Media E-Learning Interaktif Dalam Menyongsong Revolusi Industri 4.0 Pada Materi Ekosistem Untuk Siswa SMA. Biodik, 5(2), 131-138. https://doi.org/10.22437/bio.v5i2.7590.

Saputro, R. Y., Paramita, P. D., \& Warso, M. M. (2016). Pengaruh Brand Awareness, Perceived Quality, dan Price Terhadap Keputusan Pembelian Honda Vario 125 di Dealer Astra Honda Semarang. Journal of Management.

Sari, W. P. (2020). Studi Fenomenologi Penyelarasan Makna dan Pengalaman Penikmat Warung Kopi di Ambon. Jurnal Komunikasi, 12(1). https://doi.org/10.24912/jk.v12i1.7417.

Shahroom, A. A., \& Hussin, N. (2018). Industrial Revolution 4.0 and Education. International Journal of Academic Research in Business and Social Sciences, 8(9). https://doi.org/10.6007/IJARBSS/v8i9/4593.

Sihombing, F. N., Supriana, T., \& Ayu, S. F. (2021). Identifying the Factors Contributing to the Volume of Coffee Export from North Sumatra to the United States, Malaysia and Japan. Journal of Sustainable Development Education and Research, 14(2). https://doi.org/10.20961/carakatani.v36i1.43357.

Sitanggang, H. B. N., \& Dharmawan, A. (2016). Strategi Marketing Hary Tanoesoedibjo dalam Usaha Membangun Personal Branding Politik. Jurnal Penelitian Pers Dan Komunikasi Pembangunan, 20(1), 49-62. https://doi.org/10.46426/jp2kp.v20i1.43.

Surijah, E. A., Kirana, C. T., Wahyuni, N. P. J. D., Yudi, P. C., \& Astini, N. K. B. (2017). Membedah Instagram: Analisis Isi Media Sosial Pariwisata Bali. Intuisi: Jurnal Psikologi Ilmiah, 9(1), 1-17. https: //doi.org/10.15294/intuisi.v9i1.9560.

Teguh, M., \& Ciawati, S. T. (2020). Design of Digital Marketing Communication Strategy for the Hospitality Industry to Answer the Postmodern Era Challenges. Bricolage : Jurnal Magister Ilmu Komunikasi, 6(1), 51-64. https://doi.org/10.30813/bricolage.v6i01.2067. 
Vendemia, M. A., DeAndrea, D. C., \& Brathwaite, K. N. (2021). Objectifying the body positive movement: The effects of sexualizing and digitally modifying body-positive images on Instagram. Body Image, 38. https://doi.org/10.1016/j.bodyim.2021.03.017.

Widiyanti, D., \& Harti, H. (2021). Pengaruh Self-Actualization Dan Gaya Hidup Hangout Terhadap Keputusan Pembelian Di Kedai Kopi Kekinian Pada Generasi Milenial Surabaya. Jurnal Manajemen Pemasaran, 15(1), 50-60. https://doi.org/10.9744/pemasaran.15.1.50-60.

Yatsenko, Y., \& Hritonenko, N. (2020). Optimal asset replacement: Profit maximization under varying technology. International Journal of Production Economics, 228. https://doi.org/10.1016/j.ijpe.2020.107670.

Zheng, B., Liu, H., \& Davison, R. M. (2018). Exploring the relationship between corporate reputation and the public's crisis communication on social media. Public Relations Review, 44(1). https://doi.org/10.1016/j.pubrev.2017.12.006. 